\title{
The Effects of Serotonin in Immune Cells
}

\author{
Nadine Herr, Christoph Bode and Daniel Duerschmied* \\ Cardiology and Angiology I, Heart Center, Faculty of Medicine, University of Freiburg, Freiburg, Germany
}

Serotonin [5-hydroxytryptamine (5-HT)] plays an important role in many organs as a peripheral hormone. Most of the body's serotonin is circulating in the bloodstream, transported by blood platelets and is released upon activation. The functions of serotonin are mediated by members of the 7 known mammalian serotonin receptor subtype classes (15 known subtypes), the serotonin transporter (SERT), and by covalent binding of serotonin to different effector proteins. Almost all immune cells express at least one serotonin component. In recent years, a number of immunoregulatory functions have been ascribed to serotonin. In monocytes/macrophages, for example, serotonin modulates cytokine secretion. Serotonin can also suppress the release of tumor necrosis

OPEN ACCESS

Edited by: George W. Booz, University of Mississippi Medical Center School of Dentistry, United States

Reviewed by: Charles D. Nichols, LSU Health Sciences Center New Orleans, United States Maria Cecilia Giron, University of Padua, Italy

*Correspondence: Daniel Duerschmied

daniel.duerschmied@ universitaets-herzzentrum.de

Specialty section: This article was submitted to Cardiovascular Genetics and Systems Medicine, a section of the journal Frontiers in Cardiovascular Medicine

Received: 08 April 2017 Accepted: 03 July 2017 Published: 20 July 2017

Citation: Herr N, Bode C and Duerschmied D (2017) The Effects of Serotonin in Immune Cells. Front. Cardiovasc. Med. 4:48. doi: 10.3389/fCvm.2017.00048 factor- $\alpha$ and interleukin- $1 \beta$ by activating serotonin receptors. Furthermore, neutrophil recruitment and T-cell activation can both be mediated by serotonin. These are only a few of the known immunomodulatory roles of serotonin that we will review here.

Keywords: 5-hydroxytryptamine, serotonin, serotonin receptors, immune cells, immune system

\section{INTRODUCTION}

\section{Peripheral versus Central Serotonin}

Serotonin [5-hydroxytryptamine (5-HT)] has two lifes: as a neurotransmitter, it regulates sleep, appetite, mood, and other important brain functions and-separated by the blood-brain barrier and synthesized in a different way-it plays a central role in many other organ systems as a peripheral hormone (Figure 1) $(1,2)$. In fact, most of the body's serotonin is circulating in the bloodstream, transported by blood platelets (3). Most of the peripheral serotonin is synthesized by TPH1 in the enterochromaffin cells of the intestine, secreted into the bloodstream, and then taken up by circulating platelets (4). Platelets store serotonin at very high concentrations in their dense granules (at $65 \mathrm{mM}$ ) and secrete it upon activation (5). Resting plasma serotonin concentrations (around $10 \mathrm{nM}$ ) can rapidly increase to $10 \mu \mathrm{M}$ or more when platelets become activated at the site of thrombus formation or inflammation $(6,7)$.

Discovered by Rapport et al. in 1948 as a vasoconstrictor (8), new functions of serotonin have since been described continuously. These functions are mediated by members of the 7 known mammalian serotonin receptor subtype classes ( 15 known subtypes), the serotonin transporter (SERT), and by covalent binding of serotonin to different effector proteins-named "serotonylation" by Walther, Bader, and colleagues $(3,9)$. Peripheral serotonin is involved in the regulation of hemostasis, heart rate, vascular tone, intestinal motility, cell growth in liver, bone, and pulmonary arteries, and the development of heart, brain, and mammary gland (3). In addition, a number of immunoregulatory functions have been ascribed to serotonin (as described below).

Theoretically, either peripheral-i.e., predominantly platelet-derived-or central-i.e., neuronalserotonin (or both) could modulate immune responses. In their review article, from 1998, Mössner and Lesch discussed the possibility of a neural-immune interaction via the autonomic nervous system, but found only two of four criteria to be fulfilled in the case of serotonin (6): serotonin receptors 


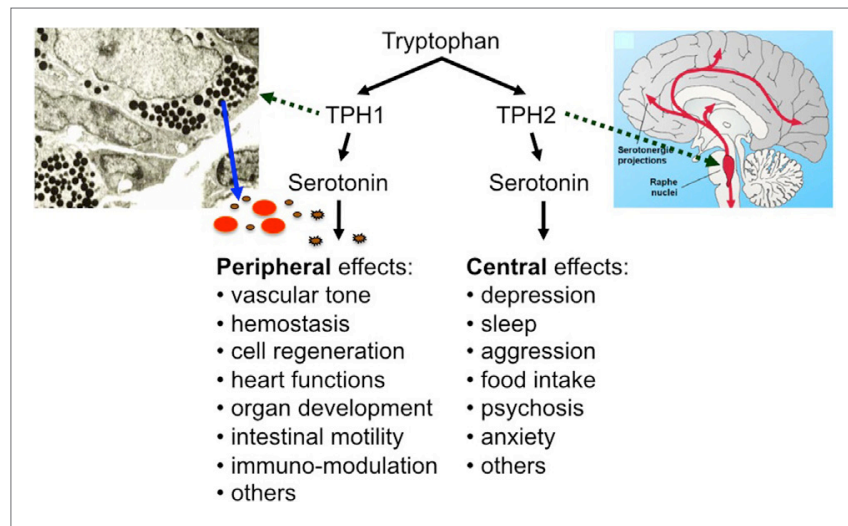

FIGURE 1 | The effects of peripheral and central serotonin.

are present on immune cells and serotonin has immunoregulatory effects. Two other criteria do not apply in the case of serotonin, though. One criterion is the local association of neurotransmitterspecific nerve fibers with immune cells (although serotonin can be taken up by noradrenergic terminals on smooth muscle cells, similar to the adrenal medulla) $(10,11)$. The other criterion is the exclusive neurotransmitter supply of the immune target cells/ organ by neurons, i.e., that the target organ could be depleted of serotonin by denervation. It is hence more likely that serotonin derived from non-neuronal sources exerts most of the immunoregulatory effects. In accordance, Roszman et al. concluded from several studies that the immunomodulatory effects of serotonin are mediated primarily through peripheral mechanisms directed toward circulating immune cells (2). Possible sources for peripheral serotonin are plasma (at rather stable, nanomolar levels), monocytes/macrophages, lymphocytes, vascular smooth muscle cells, adipocytes, mast cells (although human mast cells were long thought not to contain serotonin), and platelets $(6,12-15)$. Local mast cells (probably rodent as well as human) produce, store, and release serotonin into the extravascular space-in part, even under neural control $(6,16,17)$. Still, the vast majority of total peripheral serotonin is stored in platelets and released upon platelet activation (reaching micromolar levels) $(3,5)$. At least intravascular effects are, therefore, certainly mediated by platelet serotonin.

\section{Platelet Serotonin in Immune Responses}

In 1960, Davis et al. observed that serotonin, platelets, and inflammation were closely linked: within the first minute after injection of a lethal dose of $E$. coli endotoxin, they observed a sharp decrease in platelet count and serum serotonin, accompanied by a transient increase in plasma serotonin in dogs (18). It is now known that platelets (as transport vehicles) ensure the targeted release of serotonin in platelet-activating environments like a thrombus or an inflammatory reaction. At inflammatory sites, not only soluble factors like platelet-activating factor, complement anaphylatoxin $\mathrm{C} 5 \mathrm{a}$, and IgE-containing immune complexes but also bacteria or parasites as well as plateletendothelial interactions activate platelets, resulting in serotonin secretion $(6,19-22)$. Serotonin was shown to exert functions in innate as well as adaptive immunity. Serotonin stimulates monocytes (23) and lymphocytes (24) and hence influences the secretion of cytokines. Vascular smooth muscle cells respond to serotonin by synthesizing interleukin (IL)-6, a possibly atherogenic mechanism (25). In contrast to these descriptions of a pro-inflammatory function of serotonin, specific activation of the 5-HT2A receptor subtype in primary aortic smooth muscle cells presents a superpotent inhibition of tumor necrosis factor (TNF)- $\alpha$-mediated inflammation (26). This effect was also shown in vivo in an animal model. The systemic selective activation of the 5-HT2A receptor with (R)-DOI blocks the systemic inflammatory response by downregulating the expression of proinflammatory genes and preventing the TNF- $\alpha$-induced increase of circulating IL-6 (27).

Several other seemingly contradictory findings underline the complexity of peripheral serotonin effects. Two conflicting reports describe the interaction between leukocytes and inflamed endothelium upon serotonergic intervention. Kubes and Gaboury showed in 1996 that perivascular mast cells, which are believed to rapidly internalize serotonin and also to synthesize serotonin via TPH1, secrete serotonin to induce an early, leukocyte-independent phase of edema formation $(16,28,29)$. The recruitment of leukocytes did not seem to depend on (mast cell-derived) serotonin. In 2007, Walther et al. found that leukocyte adhesion to inflamed endothelium after injection of endotoxin depended on the activation of serotonin receptors as shown by pharmacological blockade (30). Müller et al. found in 2009 that dendritic cell migration and cytokine release was modulated by serotonin (31). In our recent studies, leukocyte recruitment to sites of inflammation is impaired in the absence of (platelet-derived) serotonin and enhanced if plasma serotonin levels rise $(32,33)$.

In 1999, Gershon commented the complexity of peripheral serotonin effects in an ironic way (34): "5-HT has delighted every pharmacologist who ever applied it to a gastrointestinal preparation; something always happens, no matter what the experimental circumstances. For example, depending on the conditions, 5-HT can make the bowel contract or relax, secrete, or not secrete. The problem that has bedeviled attempts to determine what 5-HT actually does for the gut has been that it is able to do too much." In 2009, Berger even counted a "Myriad effects of serotonin outside the central nervous system" (3). The same complexity seems to apply also to the role of serotonin in immunity [Figure 3 (40)]. In conclusion, to date, the knowledge in this field remains incomplete but assigns a variety of important immunomodulatory functions to peripheral serotonin.

\section{SEROTONERGIC COMPONENTS OF IMMUNE CELLS}

Immune cells express serotonin receptors of the 5-HT1, 5-HT2, 5-HT3, 5-HT4, and 5-HT7 classes, the serotonin transporter (SERT), and the key enzymes for serotonin synthesis (TPH) and for serotonin degradation [monoamine oxidase (MAO)]. Table 1 enlists the currently known serotonergic components of immune cells.

Eliseeva and Stefanovich first demonstrated the presence of serotonergic receptors on leukocytes in 1982 (35). In 1988, it was shown that monocytes and macrophages take up serotonin by 
SERT (similar to platelets) and metabolize it to its 5-hydroxyindole acetic acid metabolite $(12,13)$. SERT is expressed by neurons, platelets, lymphocytes, mast cells, and monocytes $(6,36)$. TPH1 is expressed by enterochromaffin cells in the intestine, monocytes, macrophages, mast cells, T-cells, and endothelium (4, 6, 13, $16,37)$. MAO is expressed by monocytes, macrophages, dendritic cells, T-cells, and platelets $(6,12,13)$.

\section{SEROTONIN EFFECTS ON IMMUNE CELLS}

\section{Platelets}

Platelets readily take up plasma serotonin released from intestinal enterochromaffin cells, store it, and release it after stimulation on the site of acute or chronic inflammation (Figure 2$)(3,38)$.

TABLE 1 | Serotonergic components of immune cells.

\begin{tabular}{lcccc}
\hline Cell type & $\begin{array}{c}\text { 5-hydroxytryptamine } \\
\text { receptors }\end{array}$ & SERT & $\begin{array}{c}\text { Tryptophan } \\
\text { hydroxylase 1 }\end{array}$ & MAO \\
\hline Monocytes and & $1 \mathrm{~A}, 1 \mathrm{E}, 2 \mathrm{~A}$, & + & + & + \\
macrophages & $3 \mathrm{~A}, 4,7$ & & & + \\
Microglia & $2 \mathrm{~B}, 5 \mathrm{~A}, 7$ & & \\
Dendritic cells & $1 \mathrm{~B}, 1 \mathrm{E}, 2 \mathrm{~A}$, & + & & + \\
Neutrophils & $2 \mathrm{~B}, 4,7$ & & & \\
& $(1 \mathrm{~A}, 1 \mathrm{~B}, 2)$ & &
\end{tabular}

Basophils

Mast cells

Eosinophils

B cells

T cells

NK cells

Platelets

Endothelial cells

Vascular smooth

muscle cells
In hemostasis, serotonin enhances platelet activation by weak agonists, such as ADP, after covalent binding to small GTPases by transaminases (named "serotonylation") (9). Although 5-HT3 receptors were identified on platelets, serotonin effects on platelets have so far been ascribed to serotonylation or activation of the main platelet serotonin receptor, the 5-HT2A receptor (39). We described in 2009 that 5-HT2A receptor stimulation without further platelet stimulation induced activation of TNF$\alpha$-converting enzyme (TACE, ADAM17) (7). This resulted in shedding of the glycoproteins Ib $\alpha$ and $\mathrm{V}$ from the von Willebrand factor receptor complex and reduced platelet adhesivity. It is not known whether serotonergic platelet stimulation influences platelet-leukocyte or platelet-endothelial interactions. Platelets play a central role in delivering serotonin to inflammatory effector cells. This represents a means of highly effective targeted release of serotonin in inflamed vessels, immediately affecting circulating and resident immune cells.

\section{Monocytes/Macrophages Serotonergic Components}

Monocytes/macrophages are believed to express the serotonergic components SERT, serotonin receptors, TPH, and MAO (Table 1) (6). Jackson et al. described in 1988 that macrophages readily take up serotonin via SERT (12). Sternberg et al. applied pharmacological studies in 1986 to first identify serotonin receptors of the 5-HT2 class on macrophages (41). Hellstrand and Hermodsson found in 1993 that 5-HT1A receptor stimulation on monocytes decreased the capacity of monocytes to suppress natural killer cell functions (42). We employed RT-PCR to reveal 5-HT1E, 5-HT2A, 5-HT3, 5-HT4, and 5-HT7 receptor mRNA expression in human monocytes (23). Finocchiaro et al. described serotonin synthesis as well as degradation in macrophages in 1988, suggesting that both, TPH and MAO may be expressed (13). Another pharmacological study suggested the presence

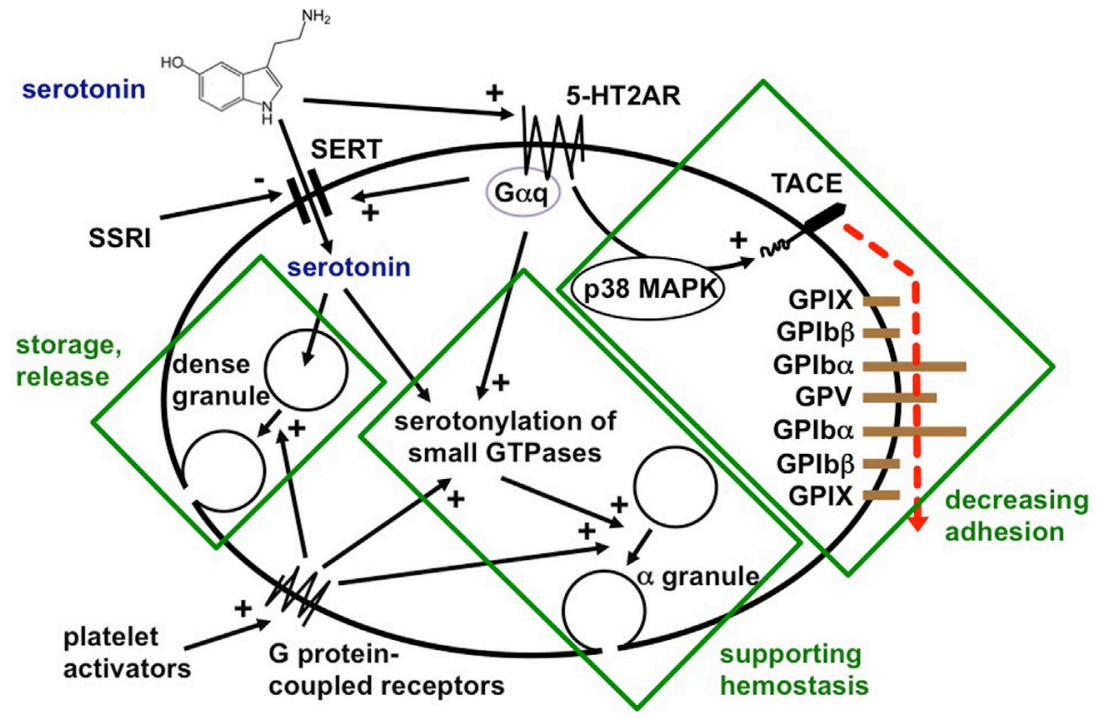

FIGURE 2 | Schematic drawing of serotonin storage in dense granules, $\alpha$-granule secretion, and TNF- $\alpha$-converting enzyme (TACE) activation in platelets [modified from Duerschmied et al. (7)]. 


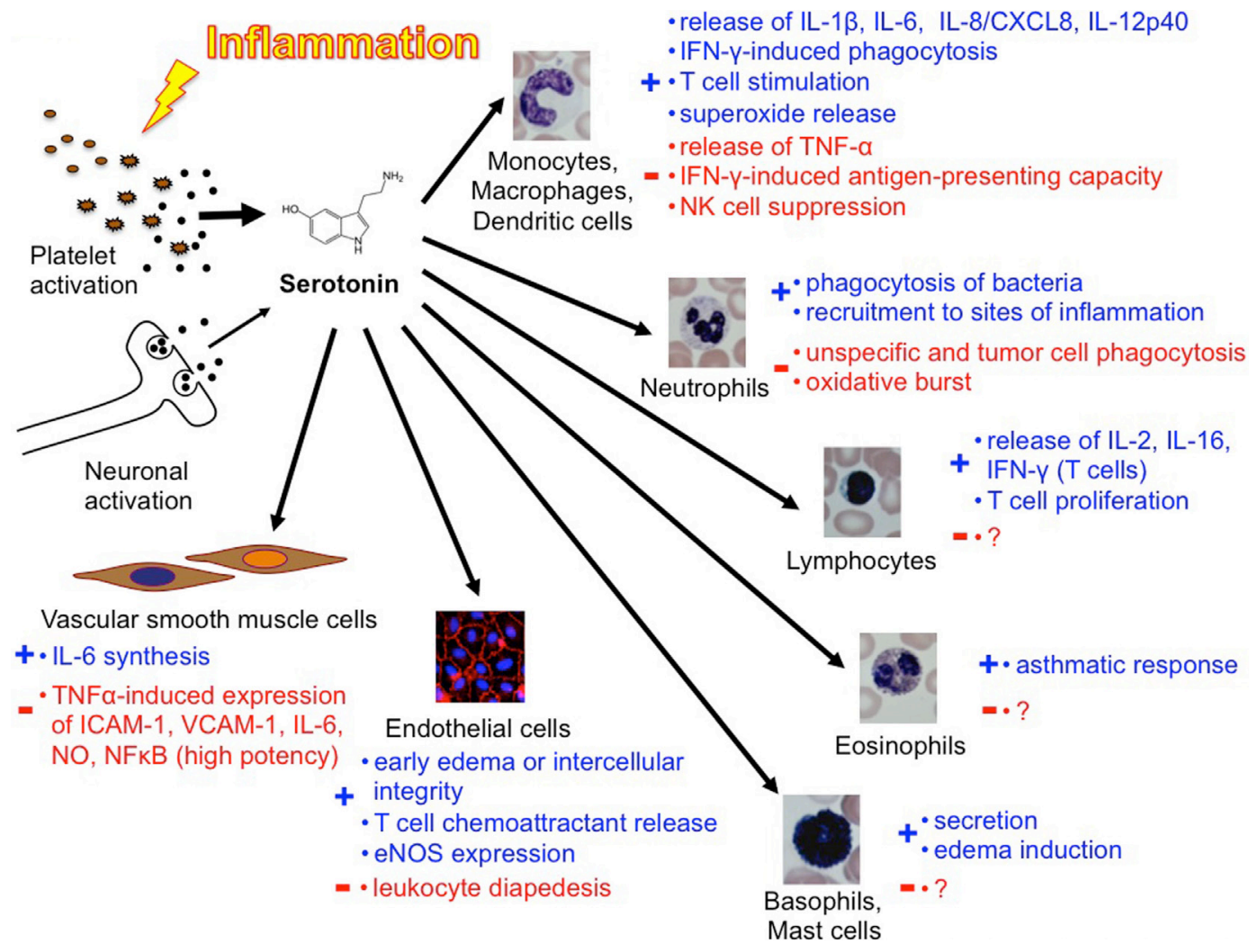

-release of IL-1 $\beta$, IL-6, IL-8/CXCL8, IL-12p40

releas

- IFN- $\gamma$-induced antigen-presenting capacity

Dendritic cells •NK cell suppression

activation

- unspecific and tumor cell phagocytosis

release of IL-2, IL-16

Neuronal

activation

ascular smooth muscle cells

- IL-6 synthesis

TNFa-induced expression

of ICAM-1, VCAM-1, IL-6

NO, NFKB (high potency)

T cell chemoattractant release

expression

\section{- edema induction}

FIGURE 3 | Overview of the complexity of the function of platelets and serotonin in inflammation and immunity [Duerschmied et al. (40)].

of TPH, SERT, and MAO in monocytes, although the findings were controversial because blockage of serotonin synthesis with the TPH inhibitor parachlorophenylalanine (PCPA) induced an increase of serotonin in monocytes and granulocytes (43). To our knowledge, protein or mRNA expression of TPH and MAO has not been confirmed in monocytes/macrophages.

\section{Serotonin Modulates Monocyte and Macrophage Function}

The studies by Sternberg et al. in 1986 and 1987 showed that serotonin had inhibitory or stimulatory effects on murine macrophages, depending on the dose $(41,44)$. Serotonin suppressed interferon (IFN-) $\gamma$-induced phagocytosis at high, but had stimulatory effects at physiological IFN- $\gamma$ concentrations. At all doses, serotonin suppressed the IFN- $\gamma$-induced antigen-presenting capacity of macrophages. Sternberg et al. also found that serotonin suppressed the IFN- $\gamma$-induced MHC class II expression but data from other groups have been conflicting (44). In 1985, Silverman et al. described specific binding of serotonin to macrophages that enhanced the release of superoxide by stimulation with phorbol myristate acetate (45).

Serotonin suppressed interactions between monocytes and NK cells, leading to an increase of NK cell functions that are normally inhibited by monocytes, such as cytotoxicity and IFN- $\gamma$ production in studies by Hellstrand and colleagues in the early 1990s $(42,46,47)$. When the group around Young and Young treated mice with PCPA to inhibit serotonin production in 1992 to 1995 , they discovered a defect in macrophage accessory function for T cell activation (48-50): the level of expression of the alpha chain IL-2 receptor (IL-2R $\alpha$ ) was reduced on splenic CD4+ cells of PCPA-treated mice but not on CD8+ cells. Moreover, splenic $\mathrm{T}$ cell proliferation in response to concanavalin A was reduced after serotonin depletion. Both IL-2R $\alpha$ expression and proliferation could be restored by exogenous serotonin and were mediated by the 5 -HT2 receptor (possibly on macrophages, although this was not proven).

\section{Serotonin Modulates Cytokine Secretion}

Arzt et al. described in 1991 that serotonin inhibited the synthesis of TNF- $\alpha$ by freshly isolated and lipopolysaccaride (LPS)stimulated human mononuclear cells (51). This effect could be inhibited by 5 -HT2 receptor blockade. In 2003, Cloez-Tayarani et al. found that serotonin inhibited the production TNF- $\alpha$ in LPS-stimulated peripheral blood mononuclear cells and increased the release of IL-1 $\beta$ (52). These authors also proposed that these effects depended on stimulation of the 5-HT2A receptor. Fiebich and coworkers described in 2004 that inhibition of 5 -HT3 receptors inhibited the LPS-induced release of TNF- $\alpha$ and IL-1 $\beta$ from human monocytes (53). Kubera et al. reported in 2005 that macrophages and lymphocytes needed serotonin at low concentrations for basal production of IL- 6 and TNF- $\alpha$, while higher concentrations of serotonin decreased the release 
of these markers via 5-HT2 receptor stimulation (54). Many of these conclusions of earlier studies that the 5-HT2A receptor was involved in several processes are based on the blockade effects of ketanserin. Ketanserin, however, is not selective for the 5-HT2A receptor and has a high affinity to block histamine $\mathrm{H} 1$ receptors as well and the anti-inflammatory effects attributed to the $2 \mathrm{~A}$ receptor may in fact be due to the $\mathrm{H} 1$ receptor.

In contrast, involving other receptors, we found in 2005 that serotonin modulated the release of the following cytokines in LPS-stimulated human blood monocytes: IL-1 $\beta$, IL-6, IL-8/ CXCL8, IL-12p40, and TNF- $\alpha$ (23). Serotonin had no effect on the production of IL-18 and IFN- $\gamma$ in our studies. The upregulation of IL-1 $\beta$, IL-6, and IL-8/CXCL8 secretion was 5-HT3 receptor mediated. Activation of the 5-HT4 and 5-HT7 receptors increased the LPS-induced release of IL-1 $\beta$, IL-6, IL-8/CXCL8, and IL-12p40, while, on the contrary, it inhibited LPS-induced TNF- $\alpha$ release. We saw no modulation of LPS-induced cytokine production at all by 5-HT1 and 5-HT2 receptor agonists.

In macrophage-like cells from human inflamed knee synovia, Seidel et al. identifed 5-HT2 and 5-HT3 receptors mediating the release of prostaglandin $\mathrm{E}_{2}$ but not TNF- $\alpha$, IL-1 $\beta$, and leukotriene B4 (55). In 2010, Tsuchida et al. reported that the prokinetic 5-HT4 receptor agonist mosapride inhibited postoperative ileus through anti-inflammatory reactions on a neuronal-macrophage axis (56). After intestinal manipulation in the rat, mosapride injection induced acetylcholine release from cholinergic myenteric neurons, which subsequently activated the $\alpha 7 \mathrm{nACh}$ receptor on activated monocytes/macrophages. This reduced not only the further recruitment of monocytes and neutrophils but also the mRNA expression of IL- $1 \beta$, IL- 6 , TNF- $\alpha$, monocyte chemoattractant protein-1, and inducible nitric oxide synthase in the inflamed muscle layer.

In summary, the discussed studies suggest that serotonin exerts complex modulatory effects on cytokine release from monocytes and macrophages. There is especially convincing evidence that the release of TNF- $\alpha$ by stimulated monocytes is inhibited by serotonin. Therefore, it can be speculated that, while serotonin activates TACE in platelets, it may inhibit TACE in monocytes $(7,57)$. The release of IL- $1 \beta$ was repeatedly reported to be suppressed by serotonin.

\section{Microglia}

Krabbe et al. found mRNA expression of 5-HT2A, 5-HT2B, 5-HT3B 5-HT5A, and 5-HT7 in brain microglia (58). They described that serotonin promoted the microglial injury-induced motility by serotonin receptor activation. In 2015, Maroteaux et al. found that the 5-HT2B receptor subtype is expressed on brain resident macrophages (microglia) and is involved in brain maturation (59). In amyotrophic lateral sclerosis, a disease associated with neuroinflammation, the upregulation of the 5-HT2B receptor was associated with slowed disease progression by less and slower degeneration of mononuclear phagocytes (60).

\section{Dendritic Cells}

Dendritic cells express several functional 5-HT receptor subtypes that are expressed in different amounts in the different stages of maturation (61). Idzko and colleagues found in 2004 that stimulation of 5-HT3, 5-HT4, and 5-HT7 receptor subtypes mediated the release of IL-1 $\beta$ and IL-8 (61).

Dendritic cells are able to take up serotonin released from activated T-cells (which synthesize serotonin) and the microenvironment via the SERT and store it in LAMP-1+ vesicles and subsequently release it via $\mathrm{Ca} 2+$ sensitive exocytosis to promote $\mathrm{T}$-cell proliferation and differentiation of naive T-cells (62). In 2009, Müller et al. described that serotonin induces oriented migration of immature dendritic cells via the activation of the 5-HT1 and 5-HT2 receptor subtypes. They also found that via the binding to 5-HT3, 5-HT4, and 5-HT7 receptors serotonin upregulates the production of IL-6 (31).

\section{Neutrophils}

About a dozen studies have addressed the effects of serotonin on neutrophils, but the results are rather controversial, including diametrically contradictory findings. To date, the existence or non-existence of serotonergic components in neutrophils has not been confirmed. Some groups propose direct serotonin effects on neutrophils while others have attributed serotonin effects on neutrophils to the release of messengers from endothelial cells, namely eicosanoids, or to direct extracellular effects of serotonin in oxidative burst (63-65).

\section{Serotonin Attenuates Oxidative Burst}

Different groups examined the production of reactive oxygen species (ROS) in neutrophils upon serotonergic stimulation. Simpson et al. found in 1991 that serotonin did not induce significant superoxide production in human neutrophils that were isolated with a Ficoll-Hypaque gradient (66). They noted, however, that, in contrast, serotonin inhibited neutrophil superoxide production upon stimulation with the chemotactic peptide fMLP at high concentrations (10 and $100 \mu \mathrm{M})$. In accordance, Jancinová et al. found in 2001 and 2003 that platelet-derived serotonin decreased ROS production by stimulated polymorphonuclear cells $(67,68)$. In 2007, Cíz et al. described that serotonin inhibited the oxidative burst of human phagocytes in whole blood in a 5-HT2 receptor-dependent manner (69). The authors proposed that this inhibitory serotonin effect may be mediated in part by the inhibition of the neutrophil lysosomal enzyme myeloperoxidase (as shown by myeloperoxidase activity inhibition in a promyelocytic cell line). In addition, Cíz's group and others showed that serotonin can directly scavenge ROS at concentrations above $10 \mu \mathrm{M}(63,69,70)$. Schuff-Werner et al. described in 1995 that serotonin acted as a scavenger of ROS and was oxidized to a homodimer during the respiratory burst in mononuclear and polymorphonuclear cells (63). In contrast to descriptions of serotonin effects on neutrophils, Pracharova et al. reported in 2010 that serotonin inhibited the oxidative burst in total leukocyte preparations from human blood, but not in isolated neutrophils (71).

Taken together, these data indicate that serotonin may decrease the production of ROS by stimulated neutrophils. Still, the study by Pracharova et al. discusses the possibility that other cell types in non-pure polymorphonuclear leukocyte preparations may have mediated these effects. In addition, serotonin's ROS-scavenging properties may primarily lie in a direct 
interaction between serotonin and ROS rather than cell-mediated effects. In conclusion, the question whether ROS production in neutrophils is modulated by serotonin has not been answered conclusively.

\section{Serotonin Influences Neutrophil Recruitment}

In 1996, Simonenkov et al. examined the chemotactic properties of non-specifically isolated human neutrophils in medium-filled chambers and found that addition of serotonin increased their movement velocity (72). In contrast, Bondesson et al. described in 1993 that while serotonin inhibited migration of Ficoll-gradientseparated mononuclear leukocytes (predominantly lymphocytes and monocytes), it had no effect on polymorphonuclear cells (mostly neutrophils) (73).

Other conflicting reports describe the interaction between leukocytes and (inflamed) endothelium upon serotonergic intervention. Doukas et al. found in 1987 and 1989 that treatment of cultured calf aortic endothelial cells with serotonin increased intercellular integrity and decreased the motility of polymorphonuclear cells (predominantly neutrophils) $(64,65)$. In contrast, Kubes et al. showed in 1996 that perivascular mast cells secrete serotonin to induce the early, leukocyteindependent phase of edema formation (28). The recruitment of leukocytes (mostly neutrophils in the early phases) did not depend on mast cell-derived serotonin. When superperfusing mesentery venules with serotonin, Kubes and coworkers found that vascular permeability increased but observed neither rolling nor adhesion of leukocytes. Then again, in 2007, Walther et al. presented evidence in the other direction: early leukocyte adhesion (within $60 \mathrm{~min}$, i.e., at least in a significant proportion neutrophils) after injection of bacterial endotoxin depended on the activation of serotonin receptors as shown by pharmacological blockade (30). Our group showed in 2013 that platelet serotonin enhances neutrophil recruitment to sites of inflammation and there was less neutrophil recruitment in the absence of serotonin (32).

\section{Serotonin May Affect the Phagocytic Activity of Neutrophils}

In a study by Nannmark et al. from 1992, direct treatment of polymorphonuclear leukocytes with serotonin suppressed tumor cell- and zymosan-induced phagocytosis in a chemiluminescence assay suggesting a possible negative role for serotonin in tumor cell destruction (74). These findings may explain the observation by Skolnik et al. (1985) that thrombocytopenia and 5-HT2 receptor antagonism with ketanserin both decreased the liver invasion by injected tumor cells (75). In contrast, as early as in 1961, Northover saw that serotonin stimulated polymorphonuclear cell phagocytosis of staphylococci (76).

When Schuff-Werner and Splettstoesser examined general biological functions of human polymorphonuclear cells after treatment with serotonin in 1999, they found complex dosedependent responses upon challenge with opsonized Staphylococcus aureus (77): at physiological serotonin concentrations (1-10 $\mu \mathrm{M})$, the antibacterial defense improved significantly (may be due to reduced autooxidation), whereas higher concentrations (1-10 mM) counteracted an efficient bacterial killing.
In conclusion, several studies suggest specific responses of neutrophils to serotonergic stimulation-and hence the presence of at least one serotonin receptor. To date, however, this has not been examined to the best of our knowledge. According to the presented studies, the main effect of serotonin on neutrophils may be the improvement of autooxidation and the suppression of oxidative burst, but neutrophil recruitment may also be influenced.

\section{Eosinophils}

Eosinophils express 5-HT1A, 5-HT1B, 5-HT1E, 5-HT2A, 5-HT2B, and 5-HT6 receptors with 5-HT2A being the most predominantly expressed (78). Via the 5-HT2A receptor eosinophil recruitment, airway inflammation, airway hyperresponsiveness, and remodeling is mediated in allergic asthma (79-81). In 2013, Kang et al. showed that serotonin induces eosinophil trafficking and recruitment via activation of ROCK, MAPK, PI3K, and the PKC-calmodulin pathway (78). Selective activation of the 5-HT2A receptor with (R)-DOI prevents eosinophil recruitment in an asthma model (82).

\section{Basophils/Mast Cells}

Mast cells in rodents are described to be an important source of serotonin, while in humans, serotonin is normally absent in mast cells (or at least found in very low concentrations). Serotonin is only found in mast cells in nameable concentrations in humans in discrete pathologies such as in the stroma of carcinoid tumors or in mastocytosis $(16,83,84)$. Rodent and human mast cells express the enzyme Tph1, so that they are capable to produce serotonin and release it to form early edema in inflammation $(28,85)$. One study of Crivellato and colleagues in 1991 even suggests that mast cells can release serotonin in part under neural control from nerve fibers containing substance $\mathrm{P}$, calcitonin gene related peptide, vasoactive intestinal polypeptide, and somatostatin in the rat mesentery with a close anatomical relationship (17). In 2006, a study of Kushnir-Sukhov and colleagues showed that mast cell adhesion and migration in human and rodent mast cells is induced by serotonin via the 5-HT1A receptor (86).

\section{Lymphocytes}

Lymphocytes take up serotonin via SERT $(36,87)$. Interestingly, serotonin uptake via SERT drove apoptosis of Burkitt lymphoma cells, which could be reversed by SSRIs, in a study by Serafeim et al. in 2002 (88).

In 2000, Stefulj et al. measured mRNA levels in spleen, thymus, and peripheral blood lymphocytes of the rat and found significant levels of 5-HT1B, 5-HT1F, 5-HT2A, 5-HT2B, 5-HT6, and 5-HT7 receptor mRNA (89). 5-HT3 receptor mRNA was only detected after stimulation with mitogens.

\section{T-Cells}

T-cells express numerous 5-HT receptors as well as all other serotonergic components (TPH1, SERT, and MAO) $(48,87,89,90)$.

In 1991, Askenase and colleagues described that serotonin released from mast cells and activating 5-HT2 receptors on 
recruited T-cells initiates the delayed-type hypersensitivity (91). In 1997, the same group showed that local secretion of serotonin from platelets initiates T-cell-dependent contact sensitivity mediated by IgE antibodys (92).

$\mathrm{T}$ cell proliferation involves 5-HT2 receptors (93). The stimulation of the 5-HT1A receptor on T-cells was shown to increase cell survival and S-phase transition by increased translocation of NFkB to the nucleus (94). In 2007, Léon-Ponte et al. showed that naive T-cells express predominantly the 5-HT7 receptor and T-cell activation was hereby enhanced through serotonin stimulation (95). Activation of the 5-HT2A receptor subtype, which is expressed in high levels in activated T-cells, with (R)-DOI represses T helper cell 2 (Th2) gene expression in allergic asthma (82).

\section{B-Cells}

In 1995, Iken and colleagues described that mitogen-stimulated B-cell proliferation was dependent on serotonin stimulation via the 5-HT1A receptor (24). Rinaldi et al. identified, in 2010, the expression of 5-HT3A in normal and neoplastic B-cells (96). In 2005, Meredith and colleagues showed that upon activation, B-cells exhibit a significant increase in SERT expression (97). As described above, serotonin uptake via SERT drives apoptosis in Burkitt lymphoma cells and could be reversed by selective serotonin reuptake inhibitors (88). Hernandez et al. showed accordingly that treatment with SSRIs increases the number of circulating B-cells (98). These findings show that serotonin influences the adaptive immune response.

\section{NK-Cells}

As described above, serotonin suppressed interactions between monocytes and NK cells, leading to an increase of NK cell functions that are normally inhibited by monocytes, such as cytotoxicity and IFN- $\gamma$ production in studies by Hellstrand and colleagues in the early 1990s (42, 46, 47). In 2008, Evans et al. showed that SSRIs enhanced the cytosolic functions of natural killer cells in vitro (99). Furthermore, 2 years later, Hernandez and colleagues showed that the long-term treatment with SSRIs enhanced the NK cell proliferation (98). The signaling mechanisms remain unclear.

\section{SEROTONIN EFFECTS ON VASCULAR SMOOTH MUSCLE CELLS AND ENDOTHELIAL CELLS}

\section{Vascular Smooth Muscle Cells}

In 1995, Ullmer et al. presented RT-PCR screening experiments with rat, porcine, human arterial, and venous vascular cells (100). The group found that vascular smooth muscle cells expressed 5-HT1D, 5-HT2A, 5-HT7, and in some experiments 5-HT2B receptor mRNA.

Watts et al. found in 2009 that serotonylation of $\alpha$-actin is necessary for contraction in smooth muscle cells (101). Ito et al. described in 2000 that serotonin increased the synthesis and release of IL-6 from vascular smooth muscle cells via the 5-HT2A receptor (25). Yu et al. found in 2008, that activation of 5-HT2A receptors in primary aortic smooth muscle cells provided a very potent inhibition of TNF-alpha-mediated inflammation (26). The TNF- $\alpha$-induced expression of intercellular adhesion molecule (ICAM)-1, vascular cell adhesion molecule-1, IL-6, nitric oxide (NO), nuclear factor- $\kappa \mathrm{B}$ was inhibited by the 5 -HT2A receptor agonist $(R)$-1-(2,5- dimethoxy-4-iodophenyl)-2-aminopropane $[(R)-\mathrm{DOI}]$ with an IC50 of 10-20 pM. This suggests a superpotent inhibitory serotonin effect and may constitute a continuous immunosuppressive mechanism at resting plasma serotonin concentrations.

\section{Endothelial Cells}

Endothelial cells express 5-HT1B (in rodent) and accordingly 5-HT1D $\beta$ (in other species), 5-HT2A, 5-HT2B, 5-HT2C, and 5-HT4 receptor mRNA (100). In 2001 and 2006, Eddahibi et al. presented evidence that pulmonary endothelial cells express SERT and TPH1 at increased levels in patients with idiopathic pulmonary artery hypertension $(37,102)$. Although at least 10 -fold lower than in the intestine, the authors found significant expression of TPH1 also in the lung of healthy subjects.

The group around Shepro presented several studies in the 1980s to show that serotonin increased intercellular endothelial integrity $(64,65,103,104)$. The conclusion from these studies was that serotonin decreased polymorphonuclear leukocyte motility, diapedesis, and albumin permeability by decreasing eicosanoid release in in vitro experiments with calf aortic endothelial cells. In contrast to these findings, Kubes et al. measured increasing leakage of labeled albumin in living rats after serotonin-release from mast cells and exogenous serotonin administration in 1996 $(28,105)$. These studies supported the theory that serotonin is a key inductor of early edema formation.

Katz et al. found in 1994 that serotonin-stimulated endothelial cells secreted an unknown endothelial cell-derived $\mathrm{T}$ cell chemoattractant and growth factor (106). This indicates that serotonin might influence leukocyte recruitment by interacting with endothelial cells. Marconi et al. found in 2003 that blocking of 5-HT2 receptors with naftidrofuryl inhibited the TNF- $\alpha$-triggered expression of ICAM- 1 expression and stress fiber formation in human umbilical vein endothelial cells ( $v i a$ NO release) (107). Our group found in 2014 that E-selectin expression on endothelium was upregulated upon higher serotonin levels in plasma (33). Although direct serotonin effects cannot be extrapolated from these results, it is possible that serotonin is involved in the regulation of endothelial adhesion receptor expression. Stimulation of 5-HT2B receptor induced endothelial nitric oxide synthase expression in human umbilical vein endothelial cells in a study by Asada et al. from 2009 suggesting that this may play an important role in tumor angiogenesis (108).

In conclusion, serotonin may regulate leukocyte recruitment and vascular integrity in inflamed vessels by modulating endothelial cells.

\section{CONCLUSION}

This review shows the complex influences of serotonin on immune cells. So far, we don't know and understand all underlying 
mechanisms, but it gets clearer, that the neurotransmitter and the peripheral hormone serotonin plays an important role in immunity and in inflammatory and immunomodulatory diseases. No matter if the serotonin derives from platelets, mast cells, T-cells, or even from neurons. For example, it influences diseases like gut inflammation (109), allergic asthma (110), rheumatoid arthritis (111), and neuroinflammation such as ALS (60) and autism (112). In the recent years, we could observe the antiinflammatory effects of antidepressant (influencing serotonin

\section{REFERENCES}

1. Walther DJ, Bader M. A unique central tryptophan hydroxylase isoform. Biochem Pharmacol (2003) 66:1673-80. doi:10.1016/S0006-2952(03) 00556-2

2. Roszman TL, Jackson JC, Cross RJ, Titus MJ, Markesbery WR, Brooks WH. Neuroanatomic and neurotransmitter influences on immune function. J Immunol (1985) 135:769s-72s.

3. Berger M, Gray JA, Roth BL. The expanded biology of serotonin. Annu Rev Med (2009) 60:355-66. doi:10.1146/annurev.med.60.042307.110802

4. Walther DJ, Peter JU, Bashammakh S, Hörtnagl H, Voits M, Fink H, et al. Synthesis of serotonin by a second tryptophan hydroxylase isoform. Science (2003) 299:76. doi:10.1126/science.1078197

5. McNicol A, Israels SJ. Platelet dense granules: structure, function and implications for haemostasis. Thromb Res (1999) 95:1-18. doi:10.1016/ S0049-3848(99)00015-8

6. Mössner R, Lesch KP. Role of serotonin in the immune system and in neuroimmune interactions. Brain Behav Immun (1998) 12:249-71. doi:10.1006/ brbi. 1998.0532

7. Duerschmied D, Canault M, Lievens D, Brill A, Cifuni SM, Bader M, et al. Serotonin stimulates platelet receptor shedding by tumor necrosis factoralpha-converting enzyme (ADAM17). J Thromb Haemost (2009) 7:1163-71. doi:10.1111/j.1538-7836.2009.03476.x

8. Rapport MM, Green AA, Page IH. Crystalline serotonin. Science (1948) 108:329-30. doi:10.1126/science.108.2804.329

9. Walther DJ, Peter JU, Winter S, Höltje M, Paulmann N, Grohmann M, et al. Serotonylation of small GTPases is a signal transduction pathway that triggers platelet alpha-granule release. Cell (2003) 115:851-62. doi:10.1016/ S0092-8674(03)01014-6

10. Holzwarth MA, Brownfield MS. Serotonin coexists with epinephrine in rat adrenal medullary cells. Neuroendocrinology (1985) 41:230-6. doi: $10.1159 / 000124182$

11. Verbeuren TJ, Jordaens FH, Herman AG. Accumulation and release of [3H]-5-hydroxytryptamine in saphenous veins and cerebral arteries of the dog. J Pharmacol Exp Ther (1983) 226:579-88.

12. Jackson JC, Walker RF, Brooks WH, Roszman TL. Specific uptake of serotonin by murine macrophages. Life Sci (1988) 42:1641-50. doi:10.1016/ 0024-3205(88)90443-2

13. Finocchiaro LM, Arzt ES, Fernández-Castelo S, Criscuolo M, Finkielman S, Nahmod VE. Serotonin and melatonin synthesis in peripheral blood mononuclear cells: stimulation by interferon-gamma as part of an immunomodulatory pathway. J Interferon Res (1988) 8:705-16. doi:10.1089/jir. 1988.8.705

14. Lesch KP, Bengel D, Heils A, Sabol SZ, Greenberg BD, Petri S, et al. Association of anxiety-related traits with a polymorphism in the serotonin transporter gene regulatory region. Science (1996) 274:1527-31. doi:10.1126/ science.274.5292.1527

15. Ni W, Geddes TJ, Priestley JR, Szasz T, Kuhn DM, Watts SW. The existence of a local 5-hydroxytryptaminergic system in peripheral arteries. $\mathrm{Br} J$ Pharmacol (2008) 154:663-74. doi:10.1038/bjp.2008.111

16. Kushnir-Sukhov NM, Brown JM, Wu Y, Kirshenbaum A, Metcalfe DD. Human mast cells are capable of serotonin synthesis and release. J Allergy Clin Immunol (2007) 119:498-9. doi:10.1016/j.jaci.2006.09.003

17. Crivellato E, Damiani D, Mallardi F, Travan L. Suggestive evidence for a microanatomical relationship between mast cells and nerve fibres containing substance $\mathrm{P}$, calcitonin gene related peptide, vasoactive intestinal polypeptide, levels in the body) in clinical practice that are, for example, mediated via macrophage modulation (113). Serotonin seems to be a promising new target when it comes to modulating immune responses.

\section{AUTHOR CONTRIBUTIONS}

$\mathrm{NH}$ and DD wrote the manuscript. CB provided helpful advice and critical reading of the paper.

and somatostatin in the rat mesentery. Acta Anat (1991) 141:127-31 doi:10.1159/000147111

18. Davis RB, Meeker WR, Mc QD. Immediate effects of intravenous endotoxin on serotonin concentrations and blood platelets. Circ Res (1960) 8:234-9. doi:10.1161/01.RES.8.1.234

19. Wagner DD, Frenette PS. The vessel wall and its interactions. Blood (2008) 111:5271-81. doi:10.1182/blood-2008-01-078204

20. McMorran BJ, Marshall VM, de Graaf C, Drysdale KE, Shabbar M, Smyth GK, et al. Platelets kill intraerythrocytic malarial parasites and mediate survival to infection. Science (2009) 323:797-800. doi:10.1126/science. 1166296

21. Timmons S, Huzoor A, Grabarek J, Kloczewiak M, Hawiger J. Mechanism of human platelet activation by endotoxic glycolipid-bearing mutant Re595 of Salmonella minnesota. Blood (1986) 68:1015-23.

22. Endo Y, Shibazaki M, Nakamura M, Takada H. Contrasting effects of lipopolysaccharides (endotoxins) from oral black-pigmented bacteria and Enterobacteriaceae on platelets, a major source of serotonin, and on histamine-forming enzyme in mice. J Infect Dis (1997) 175:1404-12. doi:10.1086/516473

23. Dürk T, Panther E, Müller T, Sorichter S, Ferrari D, Pizzirani C, et al. 5-Hydroxytryptamine modulates cytokine and chemokine production in LPS-primed human monocytes via stimulation of different 5-HTR subtypes. Int Immunol (2005) 17:599-606. doi:10.1093/intimm/dxh242

24. Iken K, Chheng S, Fargin A, Goulet AC, Kouassi E. Serotonin upregulates mitogen-stimulated B lymphocyte proliferation through 5-HT1A receptors. Cell Immunol (1995) 163:1-9. doi:10.1006/cimm.1995.1092

25. Ito T, Ikeda U, Shimpo M, Yamamoto K, Shimada K. Serotonin increases interleukin-6 synthesis in human vascular smooth muscle cells. Circulation (2000) 102:2522-7. doi:10.1161/01.CIR.102.20.2522

26. Yu B, Becnel J, Zerfaoui M, Rohatgi R, Boulares AH, Nichols CD. Serotonin 5-hydroxytryptamine(2A) receptor activation suppresses tumor necrosis factor-alpha-induced inflammation with extraordinary potency.J Pharmacol Exp Ther (2008) 327:316-23. doi:10.1124/jpet.108.143461

27. Nau F Jr, Yu B, Martin D, Nichols CD. Serotonin 5-HT2A receptor activation blocks TNF-alpha mediated inflammation in vivo. PLoS One (2013) 8:e75426. doi:10.1371/journal.pone.0075426

28. Kubes P, Gaboury JP. Rapid mast cell activation causes leukocytedependent and -independent permeability alterations. Am J Physiol (1996) 271:H2438-46.

29. Botchway SW, Parker AW, Bisby RH, Crisostomo AG. Real-time cellular uptake of serotonin using fluorescence lifetime imaging with two-photon excitation. Microsc Res Tech (2008) 71:267-73. doi:10.1002/jemt.20548

30. Walther A, Petri E, Peter C, Czabanka M, Martin E. Selective serotoninreceptor antagonism and microcirculatory alterations during experimental endotoxemia. J Surg Res (2007) 143:216-23. doi:10.1016/j.jss.2006.08.021

31. Müller T, Dürk T, Blumenthal B, Grimm M, Cicko S, Panther E, et al. 5-hydroxytryptamine modulates migration, cytokine and chemokine release and T-cell priming capacity of dendritic cells in vitro and in vivo. PLoS One (2009) 4:e6453. doi:10.1371/journal.pone.0006453

32. Duerschmied D, Suidan GL, Demers M, Herr N, Carbo C, Brill A, et al. Platelet serotonin promotes the recruitment of neutrophils to sites of acute inflammation in mice. Blood (2013) 121:1008-15. doi:10.1182/blood2012-06-437392

33. Herr N, Mauler M, Witsch T, Stallmann D, Schmitt S, Mezger J, et al. Acute fluoxetine treatment induces slow rolling of leukocytes on endothelium in mice. PLoS One (2014) 9:e88316. doi:10.1371/journal.pone.0088316 
34. Gershon MD. Review article: roles played by 5-hydroxytryptamine in the physiology of the bowel. Aliment Pharmacol Ther (1999) 13(Suppl 2):15-30. doi:10.1046/j.1365-2036.1999.00002.x-i2

35. Eliseeva LS, Stefanovich LE. [Specific binding of serotonin by blood leukocytes and peritoneal cells in the mouse]. Biokhimiia (1982) 47:810-3.

36. Faraj BA, Olkowski ZL, Jackson RT. Expression of a high-affinity serotonin transporter in human lymphocytes. Int J Immunopharmacol (1994) 16:561-7. doi:10.1016/0192-0561(94)90107-4

37. Eddahibi S, Guignabert C, Barlier-Mur AM, Dewachter L, Fadel E, Dartevelle P, et al. Cross talk between endothelial and smooth muscle cells in pulmonary hypertension: critical role for serotonin-induced smooth muscle hyperplasia. Circulation (2006) 113:1857-64. doi:10.1161/ CIRCULATIONAHA.105.591321

38. de Jong WH, Wilkens MH, de Vries EG, Kema IP. Automated mass spectrometric analysis of urinary and plasma serotonin. Anal Bioanal Chem (2010) 396:2609-16. doi:10.1007/s00216-010-3466-5

39. Stratz C, Trenk D, Bhatia HS, Valina C, Neumann FJ, Fiebich BL. Identification of 5-HT3 receptors on human platelets: increased surface immunoreactivity after activation with adenosine diphosphate (ADP) and thrombin receptor-activating peptide (TRAP). Thromb Haemost (2008) 99:784-6. doi:10.1160/TH07-10-0630

40. Duerschmied D, Bode C, Ahrens I. Immune functions of platelets. Thromb Haemost (2014) 112:678-91. doi:10.1160/TH14-02-0146

41. Sternberg EM, Trial J, Parker CW. Effect of serotonin on murine macrophages: suppression of Ia expression by serotonin and its reversal by 5-HT2 serotonergic receptor antagonists. J Immunol (1986) 137:276-82.

42. Hellstrand K, Hermodsson S. Serotonergic 5-HT1A receptors regulate a cell contact-mediated interaction between natural killer cells and monocytes. Scand J Immunol (1993) 37:7-18. doi:10.1111/j.1365-3083.1993. tb01658.x

43. Pallinger E, Csaba G. Effect of serotonin-acting agents on the serotonin content of immune cells. A peculiar observation. Cell Biochem Funct (2007) 25:581-3. doi:10.1002/cbf. 1329

44. Sternberg EM, Wedner HJ, Leung MK, Parker CW. Effect of serotonin (5-HT) and other monoamines on murine macrophages: modulation of interferon-gamma induced phagocytosis. J Immunol (1987) 138:4360-5.

45. Silverman DH, Wu H, Karnovsky ML. Muramyl peptides and serotonin interact at specific binding sites on macrophages and enhance superoxide release. Biochem Biophys Res Commun (1985) 131:1160-7. doi:10.1016/ 0006-291X(85)90212-8

46. Hellstrand K, Hermodsson S. Enhancement of human natural killer cell cytotoxicity by serotonin: role of non-T/CD16+ NK cells, accessory monocytes, and 5-HT1A receptors. Cell Immunol (1990) 127:199-214. doi:10.1016/0008-8749(90)90125-B

47. Hellstrand K, Czerkinsky C, Ricksten A, Jansson B, Asea A, Kylefjord H, et al. Role of serotonin in the regulation of interferon-gamma production by human natural killer cells. J Interferon Res (1993) 13:33-8. doi:10.1089/ jir.1993.13.33

48. Young MR, Kut JL, Coogan MP, Wright MA, Young ME, Matthews J. Stimulation of splenic T-lymphocyte function by endogenous serotonin and by low-dose exogenous serotonin. Immunology (1993) 80:395-400.

49. Kut JL, Young MR, Crayton JW, Wright MA, Young ME. Regulation of murine T-lymphocyte function by spleen cell-derived and exogenous serotonin. Immunopharmacol Immunotoxicol (1992) 14:783-96. doi:10.3109/ 08923979209009235

50. Young MR, Matthews JP. Serotonin regulation of T-cell subpopulations and of macrophage accessory function. Immunology (1995) 84:148-52.

51. Arzt E, Costas M, Finkielman S, Nahmod VE. Serotonin inhibition of tumor necrosis factor-alpha synthesis by human monocytes. Life Sci (1991) 48:2557-62. doi:10.1016/0024-3205(91)90612-F

52. Cloez-Tayarani I, Petit-Bertron AF, Venters HD, Cavaillon JM. Differential effect of serotonin on cytokine production in lipopolysaccharidestimulated human peripheral blood mononuclear cells: involvement of 5-hydroxytryptamine2A receptors. Int Immunol (2003) 15:233-40. doi:10.1093/intimm/dxg027

53. Fiebich BL, Akundi RS, Lieb K, Candelario-Jalil E, Gmeiner D, Haus U, et al. Antiinflammatory effects of 5-HT3 receptor antagonists in lipopolysaccharide-stimulated primary human monocytes. Scand J Rheumatol Suppl (2004) 119:28-32. doi:10.1080/03009740410006998
54. Kubera M, Maes M, Kenis G, Kim YK, Lason W. Effects of serotonin and serotonergic agonists and antagonists on the production of tumor necrosis factor alpha and interleukin-6. Psychiatry Res (2005) 134:251-8. doi:10.1016/j.psychres.2004.01.014

55. Seidel MF, Fiebich BL, Ulrich-Merzenich G, Candelario-Jalil E, Koch FW, Vetter H. Serotonin mediates PGE2 overexpression through 5-HT2A and 5-HT3 receptor subtypes in serum-free tissue culture of macrophage-like synovial cells. Rheumatol Int (2008) 28:1017-22. doi:10.1007/ s00296-008-0564-1

56. Tsuchida Y, Hatao F, Fujisawa M, Murata T, Kaminishi M, Seto Y, et al. Neuronal stimulation with 5-hydroxytryptamine 4 receptor induces anti-inflammatory actions via $\{$ alpha\} $7 \mathrm{nACh}$ receptors on muscularis macrophages associated with postoperative ileus. Gut (2010) 60(5):638-47. doi:10.1136/gut. 2010.227546

57. Black RA, Rauch CT, Kozlosky CJ, Peschon JJ, Slack JL, Wolfson MF, et al. A metalloproteinase disintegrin that releases tumour-necrosis factoralpha from cells. Nature (1997) 385:729-33. doi:10.1038/385729a0

58. Krabbe G, Matyash V, Pannasch U, Mamer L, Boddeke HW, Kettenmann H. Activation of serotonin receptors promotes microglial injury-induced motility but attenuates phagocytic activity. Brain Behav Immun (2012) 26:419-28. doi:10.1016/j.bbi.2011.12.002

59. Kolodziejczak M, Béchade C, Gervasi N, Irinopoulou T, Banas SM, Cordier C, et al. Serotonin modulates developmental microglia via 5-HT2B receptors: potential implication during synaptic refinement of retinogeniculate projections. ACS Chem Neurosci (2015) 6:1219-30. doi:10.1021/ cn5003489

60. El Oussini H, Bayer H, Scekic-Zahirovic J, Vercruysse P, Sinniger J, Dirrig-Grosch S, et al. Serotonin $2 \mathrm{~B}$ receptor slows disease progression and prevents degeneration of spinal cord mononuclear phagocytes in amyotrophic lateral sclerosis. Acta Neuropathol (2016) 131:465-80. doi:10.1007/ s00401-016-1534-4

61. Idzko M, Panther E, Stratz C, Müller T, Bayer H, Zissel G, et al. The serotoninergic receptors of human dendritic cells: identification and coupling to cytokine release. J Immunol (2004) 172:6011-9. doi:10.4049/ jimmunol.172.10.6011

62. O'Connell PJ, Wang X, Leon-Ponte M, Griffiths C, Pingle SC, Ahern GP. A novel form of immune signaling revealed by transmission of the inflammatory mediator serotonin between dendritic cells and T cells. Blood (2006) 107:1010-7. doi:10.1182/blood-2005-07-2903

63. Schuff-Werner P, Splettstosser W, Schmidt F, Huether G. Serotonin acts as a radical scavenger and is oxidized to a dimer during the respiratory burst of human mononuclear and polymorphonuclear phagocytes. Eur J Clin Invest (1995) 25:477-84. doi:10.1111/j.1365-2362.1995.tb01733.x

64. Doukas J, Hechtman HB, Shepro D. Vasoactive amines and eicosanoids interactively regulate both polymorphonuclear leukocyte diapedesis and albumin permeability in vitro. Microvasc Res (1989) 37:125-37. doi:10.1016/ 0026-2862(89)90032-0

65. Doukas J, Shepro D, Hechtman HB. Vasoactive amines directly modify endothelial cells to affect polymorphonuclear leukocyte diapedesis in vitro. Blood (1987) 69:1563-9.

66. Simpson PJ, Schelm JA, Jakubowski JA, Smallwood JK. The role of serotonin (5HT2) receptor blockade in myocardial reperfusion injury: effects of LY53857 in a canine model of myocardial infarction. J Pharmacol Exp Ther (1991) 258:979-85.

67. Jancinova V,NosalR,Drabikova K, DanihelovaaE.Cooperation of chloroquineand blood platelets in inhibition of polymorphonuclear leukocyte chemiluminescence. Biochem Pharmacol (2001) 62:1629-36. doi:10.1016/S0006-2952(01)00811-5

68. Jancinová V, Drábiková K, Nosál' R, Petríková M, Cíz M, Lojek A, et al. Inhibition of FMLP-stimulated neutrophil chemiluminescence by blood platelets increased in the presence of the serotonin-liberating drug chloroquine. Thromb Res (2003) 109:293-8. doi:10.1016/S0049-3848(03)00239-1

69. Cíz M, Komrsková D, Pracharová L, Okénková K, Cízová H, Moravcová A, et al. Serotonin modulates the oxidative burst of human phagocytes via various mechanisms. Platelets (2007) 18:583-90. doi:10.1080/ 09537100701471865

70. Huether G, Fettkotter I, Keilhoff G, Wolf G. Serotonin acts as a radical scavenger and is oxidized to a dimer during the respiratory burst of activated microglia. J Neurochem (1997) 69:2096-101. doi:10.1046/j.1471-4159.1997. 69052096.x 
71. Pracharova L, Okenkova K, Lojek A, Ciz M. Serotonin and its 5-HT(2) receptor agonist DOI hydrochloride inhibit the oxidative burst in total leukocytes but not in isolated neutrophils. Life Sci (2010) 86:518-23. doi:10.1016/j.lfs.2010.02.003

72. Simonenkov AP, Fedorov VD, Galkin AA. [Serotonin deficiency in neutrophils]. Biull Eksp Biol Med (1996) 121:467-9. doi:10.1007/BF02446749

73. Bondesson L, Nordlind K, Liden S, Sundstrom E. Inhibiting effects of serotonin and serotonin antagonists on the migration of mononuclear leucocytes. Immunopharmacol Immunotoxicol (1993) 15:243-50. doi:10.3109/ 08923979309025997

74. Nannmark U, Sennerby L, Bjursten LM, Skolnik G, Bagge U. Inhibition of leukocyte phagocytosis by serotonin and its possible role in tumor cell destruction. Cancer Lett (1992) 62:83-6. doi:10.1016/0304-3835(92) 90202-7

75. Skolnik G, Bagge U, Blomqvist G, Dahlstrom A, Ahlman H. Involvement of platelet-released 5-HT in tumor cell lodgement. J Surg Res (1985) 38:559-67. doi:10.1016/0022-4804(85)90076-9

76. Northover BJ. The effect of histamine and 5-hydroxytryptamine on phagocytosis of staphylococci in vitro by polymorphs and macrophages. J Pathol Bacteriol (1961) 82:355-61. doi:10.1002/path.1700820213

77. Schuff-Werner P, Splettstoesser W. Antioxidative properties of serotonin and the bactericidal function of polymorphonuclear phagocytes. Adv Exp Med Biol (1999) 467:321-5. doi:10.1007/978-1-4615-4709-9_41

78. Kang BN, Ha SG, Bahaie NS, Hosseinkhani MR, Ge XN, Blumenthal MN, et al. Regulation of serotonin-induced trafficking and migration of eosinophils. PLoS One (2013) 8:e54840. doi:10.1371/journal.pone.0054840

79. Boehme SA, Lio FM, Sikora L, Pandit TS, Lavrador K, Rao SP, et al. Cutting edge: serotonin is a chemotactic factor for eosinophils and functions additively with eotaxin. J Immunol (2004) 173:3599-603. doi:10.4049/ jimmunol.173.6.3599

80. De Bie JJ, Henricks PA, Cruikshank WW, Hofman G, Jonker EH, Nijkamp FP. Modulation of airway hyperresponsiveness and eosinophilia by selective histamine and 5-HT receptor antagonists in a mouse model of allergic asthma. Br J Pharmacol (1998) 124:857-64. doi:10.1038/sj.bjp. 0701901

81. Lima C, Souza VM, Soares AL, Macedo MS, Tavares-de-Lima W, Vargaftig BB. Interference of methysergide, a specific 5-hydroxytryptamine receptor antagonist, with airway chronic allergic inflammation and remodelling in a murine model of asthma. Clin Exp Allergy (2007) 37:723-34. doi:10.1111/j.1365-2222.2007.02700.x

82. Nau F Jr, Miller J, Saravia J, Ahlert T, Yu B, Happel KI, et al. Serotonin 5-HT(2) receptor activation prevents allergic asthma in a mouse model. Am J Physiol Lung Cell Mol Physiol (2015) 308:L191-8. doi:10.1152/ajplung. 00138.2013

83. Meredith EJ, Chamba A, Holder MJ, Barnes NM, Gordon J. Close encounters of the monoamine kind: immune cells betray their nervous disposition. Immunology (2005) 115:289-95. doi:10.1111/j.1365-2567.2005. 02166.x

84. Morishima T. 5-hydroxytryptamine (serotonin) and 5-hydroxytryptophan in mast cells of human mastocytosis. Tohoku J Exp Med (1970) 102:121-6. doi:10.1620/tjem.102.121

85. Inoue $\mathrm{H}$, Nagata $\mathrm{N}$, Koshihara Y. Participation of serotonin in capsaicininduced mouse ear edema. Jpn J Pharmacol (1995) 69:61-8. doi:10.1254/ jjp.69.61

86. Kushnir-Sukhov NM, Gilfillan AM, Coleman JW, Brown JM, Bruening S, Toth $\mathrm{M}$, et al. 5-hydroxytryptamine induces mast cell adhesion and migration. J Immunol (2006) 177:6422-32. doi:10.4049/jimmunol.177.9.6422

87. Gordon J, Barnes NM. Lymphocytes transport serotonin and dopamine: agony or ecstasy? Trends Immunol (2003) 24:438-43. doi:10.1016/ S1471-4906(03)00176-5

88. Serafeim A, Grafton G, Chamba A, Gregory CD, Blakely RD, Bowery NG, et al. 5-Hydroxytryptamine drives apoptosis in biopsylike Burkitt lymphoma cells: reversal by selective serotonin reuptake inhibitors. Blood (2002) 99:2545-53. doi:10.1182/blood.V99.7.2545

89. Stefulj J, Jernej B, Cicin-Sain L, Rinner I, Schauenstein K. mRNA expression of serotonin receptors in cells of the immune tissues of the rat. Brain Behav Immun (2000) 14:219-24. doi:10.1006/brbi.1999.0579

90. Aune TM, McGrath KM, Sarr T, Bombara MP, Kelley KA. Expression of 5 HT1a receptors on activated human $\mathrm{T}$ cells. Regulation of cyclic AMP levels and T cell proliferation by 5-hydroxytryptamine. J Immunol (1993) 151:1175-83.

91. Askenase PW, Herzog WR, Millet I, Paliwal V, Ramabhadran R, Rochester C, et al. Serotonin initiation of delayed-type hypersensitivity: mediation by a primitive Thy-1+ antigen-specific clone or by specific monoclonal IgE antibody. Skin Pharmacol (1991) 4(Suppl 1):25-42. doi:10.1159/ 000210981

92. Matsuda H, Ushio H, Geba GP, Askenase PW. Human platelets can initiate T cell-dependent contact sensitivity through local serotonin release mediated by IgE antibodies. J Immunol (1997) 158:2891-7.

93. Nordlind K, Sundstrom E, Bondesson L. Inhibiting effects of serotonin antagonists on the proliferation of mercuric chloride stimulated human peripheral blood T lymphocytes. Int Arch Allergy Immunol (1992) 97:105-8. doi:10.1159/000236104

94. Abdouh M, Albert PR, Drobetsky E, Filep JG, Kouassi E. 5-HT1A-mediated promotion of mitogen-activated $\mathrm{T}$ and $\mathrm{B}$ cell survival and proliferation is associated with increased translocation of NF-kappaB to the nucleus. Brain Behav Immun (2004) 18:24-34. doi:10.1016/S0889-1591(03)00088-6

95. Léon-Ponte M, Ahern GP, O’Connell PJ. Serotonin provides an accessory signal to enhance T-cell activation by signaling through the 5-HT7 receptor. Blood (2007) 109:3139-46. doi:10.1182/blood-2006-10-052787

96. Rinaldi A, Chiaravalli AM, Mian M, Zucca E, Tibiletti MG, Capella C, et al. Serotonin receptor $3 \mathrm{~A}$ expression in normal and neoplastic B cells. Pathobiology (2010) 77:129-35. doi:10.1159/000292646

97. Meredith EJ, Holder MJ, Chamba A, Challa A, Drake-Lee A, Bunce CM, et al. The serotonin transporter (SLC6A4) is present in B-cell clones of diverse malignant origin: probing a potential anti-tumor target for psychotropics. FASEB J (2005) 19:1187-9. doi:10.1096/fj.04-3477fje

98. Hernandez ME, Martinez-Fong D, Perez-Tapia M, Estrada-Garcia I, Estrada-Parra S, Pavón L. Evaluation of the effect of selective serotoninreuptake inhibitors on lymphocyte subsets in patients with a major depressive disorder. Eur Neuropsychopharmacol (2010) 20:88-95. doi:10.1016/j. euroneuro.2009.11.005

99. Evans DL, Lynch KG, Benton T, Dubé B, Gettes DR, Tustin NB, et al. Selective serotonin reuptake inhibitor and substance $\mathrm{P}$ antagonist enhancement of natural killer cell innate immunity in human immunodeficiency virus/ acquired immunodeficiency syndrome. Biol Psychiatry (2008) 63:899-905. doi:10.1016/j.biopsych.2007.08.012

100. Ullmer C, Schmuck K, Kalkman HO, Lubbert H. Expression of serotonin receptor mRNAs in blood vessels. FEBS Lett (1995) 370:215-21. doi:10.1016/0014-5793(95)00828-W

101. Watts SW, Priestley JR, Thompson JM. Serotonylation of vascular proteins important to contraction. PLoS One (2009) 4:e5682. doi:10.1371/journal. pone. 0005682

102. Eddahibi S, Humbert M, Fadel E, Raffestin B, Darmon M, Capron F, et al. Serotonin transporter overexpression is responsible for pulmonary artery smooth muscle hyperplasia in primary pulmonary hypertension. J Clin Invest (2001) 108:1141-50. doi:10.1172/JCI200112805

103. Shepro D, Welles SL, Hechtman HB. Vasoactive agonists prevent erythrocyte extravasation in thrombocytopenic hamsters. Thromb Res (1984) 35:421-30. doi:10.1016/0049-3848(84)90234-2

104. Welles SL, Shepro D, Hechtman HB. Vasoactive amines modulate actin cables (stress fibers) and surface area in cultured bovine endothelium. J Cell Physiol (1985) 123:337-42. doi:10.1002/jcp.1041230307

105. Kubes P, Granger DN. Leukocyte-endothelial cell interactions evoked by mast cells. Cardiovasc Res (1996) 32:699-708. doi:10.1016/0008-6363(96) 00118-6

106. Katz MF, Farber HW, Dodds-Stitt Z, Cruikshank WW, Beer DJ. Serotoninstimulated aortic endothelial cells secrete a novel T lymphocyte chemotactic and growth factor. J Leukoc Biol (1994) 55:567-73.

107. Marconi A, Darquenne S, Boulmerka A, Mosnier M, D’Alessio P. Naftidrofuryl-driven regulation of endothelial ICAM-1 involves nitric oxide. Free Radic Biol Med (2003) 34:616-25. doi:10.1016/S0891-5849(02) 01368-0

108. Asada M, Ebihara S, Yamanda S, Niu K, Okazaki T, Sora I, et al. Depletion of serotonin and selective inhibition of $2 \mathrm{~B}$ receptor suppressed tumor angiogenesis by inhibiting endothelial nitric oxide synthase and extracellular signal-regulated kinase 1/2 phosphorylation. Neoplasia (2009) 11:408-17. doi:10.1593/neo.81630 
109. Khan WI, Ghia JE. Gut hormones: emerging role in immune activation and inflammation. Clin Exp Immunol (2010) 161:19-27. doi:10.1111/j. 1365-2249.2010.04150.x

110. Dürk T, Duerschmied D, Müller T, Grimm M, Reuter S, Vieira RP, et al. Production of serotonin by tryptophan hydroxylase 1 and release via platelets contribute to allergic airway inflammation. Am J Respir Crit Care Med (2013) 187:476-85. doi:10.1164/rccm.201208-1440OC

111. Bird H, Broggini M. Paroxetine versus amitriptyline for treatment of depression associated with rheumatoid arthritis: a randomized, double blind, parallel group study. J Rheumatol (2000) 27:2791-7.

112. Jaiswal P, Mohanakumar KP, Rajamma U. Serotonin mediated immunoregulation and neural functions: complicity in the aetiology of autism spectrum disorders. Neurosci Biobehav Rev (2015) 55:413-31. doi:10.1016/j. neubiorev.2015.05.013
113. Nazimek K, Strobel S, Bryniarski P, Kozlowski M, Filipczak-Bryniarska I, Bryniarski $\mathrm{K}$. The role of macrophages in anti-inflammatory activity of antidepressant drugs. Immunobiology (2016) 222(6):823-30. doi:10.1016/j.imbio.2016.07.001

Conflict of Interest Statement: The authors declare that the research was conducted in the absence of any commercial or financial relationships that could be construed as a potential conflict of interest.

Copyright (c) 2017 Herr, Bode and Duerschmied. This is an open-access article distributed under the terms of the Creative Commons Attribution License (CC BY). The use, distribution or reproduction in other forums is permitted, provided the original author(s) or licensor are credited and that the original publication in this journal is cited, in accordance with accepted academic practice. No use, distribution or reproduction is permitted which does not comply with these terms. 